\title{
Risk Analysis and Impact of Raw Materials for Achievement of Sustainable Quality of Biscuit Products
}

\author{
Marieta Stefanova \\ Department of Commodity Science, Faculty of Economics, Varna University of Economics, bul. Knyaz Boris I № 77, Varna BG-9002, \\ Bulgaria
}

\begin{abstract}
This publication considers the possibilities of achieving sustainable indicators for the quality of biscuit products through management of purchasing processes, risk analysis and impact study of raw materials as part of the quality management system. On the basis of the results from this research it can be assumed that the Failure Modes and Effects Analysis (FMEA) can be applied in risk management and risk analysis of raw materials used in manufacturing the product and in achieving sustainable quality of the finished product. Analysis of raw materials impact was carried out with the aim of achieving sustainable sensory indicators for biscuit products. It was established that the integrated approach, applied in managing and solving problems related to authenticity, quality and safety of raw materials, contributes to manufacturing biscuit products with sustainable quality and in conformity with customer requirements.
\end{abstract}

Key words: Raw materials, integrated management system, biscuit products.

\section{Introduction}

A number of researchers have established that the quality of raw materials has impact on the properties of doughs and the structure of biscuit products, among them Baltsavias [1], Jacob [2], Laguna [3], Abboud [4], Chevallier [5].

The publications we examined outlined the following important aspects characterizing the impact of the different raw materials in biscuit manufacturing and the risks of using them:

Wheat flour. Flour is the main ingredient used in the manufacturing process and its quality is related to the texture and form of biscuit products [6]. Although other types of flour also became widely used in the past few years (rice, corn and spelt), wheat flour still holds priority. The main indicator for determining the quality of the flour used in manufacturing baker's wares is the gluten extraction. Gluten adds elasticity to the biscuit dough, which helps maintain its form in the fermentation process [7].

Corresponding author: Marieta Stefanova, Ph.D. student, research fields: food quality and safety management system.
Sweeteners. Sweeteners are the second basic component used in biscuit manufacturing. They add sweetness, influence the texture and colour of the product and at the same time help increasing the shelf life [8]. The combination of sucrose and sugar syrup is included in most biscuit products, whereby sucrose contributes more to the texture during baking [9], while sugar syrup determines the colour of the end product by means of the non-enzymatic browning reaction [10]. The risk which may arise in using these raw materials is linked to the reaction between reducing sugars and free amino acids and peptides when heated, knows as "Maillard reaction" [11]. The positive effect from this reaction can be found in the faster formation of the characteristic colour of the product at much lower temperatures than necessary for the caramelization of sugars. Slow baking at low temperatures can achieve the same colouring effect as with fast baking at high temperatures. Giving brown nuances to the biscuit surface can be achieved as result of including glucose, invert syrups or lactose, which would allow considerable control on the Maillard reaction. The more violent and uncontrolled 
Maillard reaction can result in softening of biscuit products, excessive or uneven browning of the surface and consequently reducing the nutrition value of the product.

Fats. The third main component in biscuit manufacturing are fats. They help forming the texture, the taste and flavour properties of the product. The basic function of fats is to enrich the dough, giving the typical crumbly biscuit texture of the finished product. Both animal fats (cows' butter) and vegetable fats (palm oil, peanut butter, etc.) are used in biscuit manufacturing. In the course of kneading the dough the fats are included in the gluten structure to add soft and smooth texture to the ready products [2]. Fats are used as main raw material also in preparing semi-finished materials for manufacturing biscuit products in filling creams, different sprinkles and glaze coatings. Most fats liquefy in normal atmospheric conditions and for this reason are unsuitable to be used in their native form. The properties of fats can be improved by hydrogenation, which increases the melting point. Since fats which are solid at ambient temperature are preferable, palm oil finds widest application in biscuit manufacturing (with melting point about $36^{\circ} \mathrm{C}$ ). In recent years there is a tendency to decrease fat quantity in the composition of biscuit products for health reasons. This change in the recipe requires using more water in order to reach the appropriate dough consistency. Adding more water leads to hydration of the proteins in the dough and formation of more gluten, which is in turn reflected in the harder consistency of the dough and the finished product.

Water. Water has various functions in biscuit manufacturing: it dissolves the micro- and the macro-components in raw materials, facilitates the formation of gluten and helps control the dough temperature [12]. Water does not influence the nutritive value of the product, but promotes the process of mixing the ingredients, as result of which the products get hard texture and crispy consistency after baking. Most of added water evaporates during baking.

Milk. Milk and milk products contribute to increasing the nutritive value, improvement of colour, taste and consistency of the finished products [13]. Milk components facilitate to a large extent the Maillard reaction and are therefore used in small quantities in order to prevent strong browning of the surface. Milk powder finds widest application as raw materials, because it is processed and preserved easier than fresh milk. Milk powder and powdered whey products contribute to the flavour of biscuit creams. The main risk is using milk powder which is related to its inadequate solubility. This results in the formation of lumps in the dough, which get dark brown after baking the biscuits. This problem is usually overcome through dissolving in advance the milk powder in cold water before adding it to other ingredients. It is recommended to buy milk powder with specification which allows no more than $0.1 \%$ water insoluble matter. Due to the essential importance of milk products for the organoleptic properties of biscuits, it is necessary to exercise strict control. Another risk arises with using cows' butter-at room temperature it becomes quickly rancid, but in order to achieve complete homogenization with the other ingredients, it cannot be used in solid form or having temperature of $4{ }^{\circ} \mathrm{C}$. This requires its tempering immediately before use.

Egg mixture. Egg products used in manufacturing biscuits are usually in liquid or dry form (for example egg mixture and egg powder), due to the fast denaturation of egg proteins. Egg powder, due to the high temperature at which it is obtained, does not have the same foaming qualities as fresh eggs or the well-tempered egg mixture immediately before use [14]. Egg products are a very good medium for the development of micro-organisms, which requires control over the conditions of their processing and storage in the safety management system or the implementation of good manufacturing practices. 
Nuts and dry fruits. The different nuts and dry fruits have considerable contribution for the taste and the structural properties of the finished products. Some kinds of nuts are allergens and may cause health problems in consumers. The cross-contamination with allergens in the finished products can have as a source the supplied material. This requires efficient control of suppliers before making the actual supply and observing the statutory regulations for labeling such products. Nuts do not have outstanding flavouring properties and for this reason their flavour can be distinguished in the finished products only if they have been used in sufficient quantity. Usually, nuts and dry fruits are placed on the surface of the biscuit products. On the one hand, the risk is related to dimensional characteristics-oversized nuts can degrade the texture, while undersized nuts are not noticeable by the consumer, they do not have sufficient flavour and distinctive contribution. On the other hand, nuts are the main source of physical contamination in the finished product (chiefly due to non-compliance with the hygienic requirements for their processing at the place of extraction or storage) - dust, stones, etc. The poorly cleaned walnut shells are the most common cause for excluding walnut biscuits from the product range list of many producers [15].

Cocoa products. Cocoa products are widely used raw materials in biscuit productions. They have greatest impact on the colour and flavour of products. The chocolate composition is legally regulated with Directive 2000/36/EC due to the many product substitutes of cocoa butter. The story of the greatest technological progress in chocolate production is connected with the achievements of the Nestle company in manufacturing milk chocolate and mixing cocoa and milk fats, overcoming the water presence in the composition [16]. The moisture content of chocolate products is critical for their viscosity, which should not exceed $1 \%$. The specially developed cocoa-based couverture coatings are used for enrobing and coating biscuit products. The couverture has specific physical properties, making it suitable for countries with warm climate and is much cheaper than chocolate coatings. According to Afoakawa, its advantages can be summarized as follows [17]: it is more economical and easier for manufacturing; it has higher melting point; it fills better the cracks in the strongly porous biscuits by enrobing; it is offered in great variety of colours and flavours. The risks related to the use of couverture are less attractive sensory profile and specific waxy feeling in the mouth when consuming the product; absence of the typical chocolate taste due to the cocoa butter in the chocolate; the couverture has a greater tendency to whiten during storage; it cannot be labeled as chocolate.

Micro raw materials. Most often they are used as surface-active agents (emulsifiers), whose main function is to increase the capacity for more even distribution of fats on other main ingredients. Preference is given to the use of lecithin, mono- and di-glycerides, esters, polysorbate, etc. The surface-active substances form complex structure with the proteins and the starch, decreasing in this way the deformation of dough during baking [18]. The viscosity of chocolate products is essential for the quality of couverture coatings used in biscuits. Lecithin is used to improve the viscosity in proportion $0.4 \%$ to $0.5 \%$ of the total chocolate mass [19]. The main risk in this case is that the effect of lecithin is not displayed at temperature above $60{ }^{\circ} \mathrm{C}$, which is why when manipulating the couverture, this temperature limit should not be exceeded.

Food additives are used in order to increase the shelf life, to facilitate the processing of doughs and to improve the sensory qualities of the finished products. Various colous, acidity regulators, flavours, preservatives and stabilizers are used as food additives. Cooking salt is used as additive chiefly to improve the taste and to slow down the speed of fermentation. The most widely used raising agents are sodium bicarbonate and ammonium bicarbonate, which emit 
gases $\left(\mathrm{CO}_{2}\right)$ and ammonia in the course of baking, which adds porous structure to the finished products. As a rule, the formation of taste and smell of biscuit products covers the whole process of manufacturing and is rarely due only to the use of flavourings. The natural flavouring substances should be tested and carefully selected before use, in order to ensure sustainable quality. Adding suitable kinds and quantities of emulsifiers facilitates both decreasing the fat content and achieving optimum structure of the biscuit product. Emulsifiers should be used according to the need in minimum concentrations, because if used excessively, there is a risk of deteriorating the taste of the product.

The impact of the raw materials described above is summarized in Table 1.

It is clear from Table 1 that the achievement of sustainable characteristics of the final product is not due to the use of a single raw material or a group of materials, but to the interaction between all ingredients. The quality of biscuit products is determined by the properties of the dough used to make the products. The dough is not a simple mixture of raw materials, but interaction between the ingredients participating in its composition [5]. The texture, the taste and the overall sensory profile of biscuit products are due first and foremost to the fats, the flour and the water.

The examination of the impact of raw materials in scientific publications reveals the prevalent opinion that one can strive for sustainable quality of the final product through risk analysis and management of the raw materials used in manufacturing.

The standard IEC 31010:2009 Risk Management-Risk Assessment Techniques indicates a total of 31 methods for identification, analysis and assessment of the risk. The recommended method for functional analysis with the possibility of ensuring quantitative results given in the standard is Failure Modes and Effects Analysis (FMEA).

These conditions made it necessary to choose exactly the FMEA method as the method for risk identification, analysis and assessment analysis.

The purpose of this research is the application of

Table 1 Impact of raw materials on the quality of biscuit products.

\begin{tabular}{|c|c|c|c|c|c|c|c|}
\hline \multirow{2}{*}{ Raw material } & \multicolumn{7}{|c|}{ Impact of raw material on: } \\
\hline & Dough properties & Product structure & Texture & Taste & Smell & Colour & Shelf life \\
\hline Wheat flour & M & M & $\mathrm{L}$ & M & $\mathrm{N}$ & $\mathrm{N}$ & $\mathrm{N}$ \\
\hline Fats and oils & M & M & M & M & M & $\mathrm{L}$ & $\mathrm{N}$ \\
\hline Water & M & M & $\mathrm{N}$ & M & $\mathrm{N}$ & $\mathrm{N}$ & M \\
\hline Fibers & $\mathrm{L}$ & $\mathrm{L}$ & $\mathrm{L}$ & $\mathrm{L}$ & $\mathrm{N}$ & $\mathrm{N}$ & M \\
\hline Soy flour & $\mathrm{N}$ & $\mathrm{N}$ & $\mathrm{N}$ & $\mathrm{N}$ & $\mathrm{N}$ & $\mathrm{N}$ & $\mathrm{N}$ \\
\hline Cocoa powder & $\mathrm{N}$ & $\mathrm{N}$ & $\mathrm{N}$ & $\mathrm{L}$ & M & M & $\mathrm{N}$ \\
\hline Sucrose & $\mathrm{L}$ & M & $\mathrm{L}$ & M & M & M & M \\
\hline Dextrose/glucose syrup & $\mathrm{L}$ & $\mathrm{L}$ & $\mathrm{L}$ & $\mathrm{L}$ & $\mathrm{L}$ & M & M \\
\hline Invert sugar & $\mathrm{L}$ & $\mathrm{L}$ & $\mathrm{N}$ & $\mathrm{L}$ & M & M & M \\
\hline Egg mixture & $\mathrm{N}$ & $\mathrm{N}$ & $\mathrm{N}$ & $\mathrm{N}$ & $\mathrm{N}$ & $\mathrm{L}$ & M \\
\hline Raising agents & $\mathrm{N}$ & $\mathrm{L}$ & M & $\mathrm{L}$ & $\mathrm{L}$ & $\mathrm{N}$ & $\mathrm{N}$ \\
\hline Dry fruits & $\mathrm{N}$ & $\mathrm{N}$ & $\mathrm{N}$ & $\mathrm{L}$ & $\mathrm{L}$ & $\mathrm{N}$ & $\mathrm{L}$ \\
\hline Block chocolate & $\mathrm{N}$ & $\mathrm{N}$ & $\mathrm{N}$ & $\mathrm{L}$ & $\mathrm{L}$ & $\mathrm{N}$ & $\mathrm{N}$ \\
\hline Candied fruits & $\mathrm{N}$ & $\mathrm{N}$ & $\mathrm{N}$ & $\mathrm{L}$ & M & $\mathrm{N}$ & $\mathrm{L}$ \\
\hline Salt & $\mathrm{N}$ & $\mathrm{N}$ & $\mathrm{N}$ & $\mathrm{N}$ & M & $\mathrm{N}$ & $\mathrm{L}$ \\
\hline Enzymes & $\mathrm{N}$ & M & $\mathrm{N}$ & $\mathrm{N}$ & $\mathrm{N}$ & $\mathrm{N}$ & $\mathrm{N}$ \\
\hline Milk Powder & $\mathrm{L}$ & $\mathrm{L}$ & $\mathrm{N}$ & M & $\mathrm{L}$ & $\mathrm{L}$ & M \\
\hline Whey powder прах & $\mathrm{L}$ & $\mathrm{L}$ & $\mathrm{N}$ & $\mathrm{N}$ & $\mathrm{L}$ & $\mathrm{L}$ & $\mathrm{N}$ \\
\hline
\end{tabular}

Note: $\mathrm{M}=$ major contribution; $\mathrm{L}=$ limited contribution; $\mathrm{N}=$ no significant contribution.

Source: Overview of publications and study of Cauvain and Young [20]. 
the FMEA in the risk management and analysis of the raw materials used in the product, in order to achieve sustainable quality of the final product.

\section{Materials and Methods}

This research was carried out in two biscuit manufacturing plants in Bulgaria. The production of the plants is sold to international markets. The research covered 68 different suppliers, and an analysis was carried out for the risk and contribution of each supplied raw material. The processes involved were investigated and the ways for building a systematic approach for the management of purchasing the raw materials and supplies were analyzed, in order to minimize the risk from selling unfit for consumption or poor quality products because of raw materials which do not meet the specifications. The data from the research were collected through observation and analysis of the various stages in the process from the improvement of supplier to the delivery of raw materials and their correct storage. Additional information was received by the top management of the company and the quality management system.

The main method we used was the FMEA-a standardized method intended for identification and assessment of potential unconformities (defects) in the performance of a particular process in accordance with its specification [21]. The method was used in risk analysis and management of raw materials, the possible failures of the system and the actions for elimination of such failures.

The main purpose of the FMEA method is to determine the risk priority number (RPN) as product of the following three components:

$$
\mathrm{RPN}=(\mathrm{P}) *(\mathrm{R}) *(\mathrm{~N})
$$

where:

- Severity $(\mathrm{P})$ is the significance of the effect;

- Probability (R) is the occurrence of failure;

- Detection $(\mathrm{N})$ is the likelihood that the unconformity will be detected before the product has reached the customer.

\section{Results and Analysis}

It is established that all external suppliers whose product, service or processes have an impact on the products, services or processes offered by the company, are assessed for quality and their capacity to deliver products and services in accordance with the requirements. The company makes assessment of the external suppliers and purchases raw materials and supplies only from the ones who can meet the approval requirements. The approval of suppliers is carried out by analyzing the risks and the critical factors for conformity of purchased raw materials and supplies. The results from the risk analysis and the impact of the raw material for the achievement of sustainable characteristics of the finished product are determining factors in applying the control for minimizing the risk. The risk analysis of raw materials and suppliers made by us included three important components:

- Assessment and analysis of critical factors for the approval of a supplier, which includes also analysis of the system insufficiency (Table 2);

- Determining a preliminary RPN by using FMEA. The application of the method allowed us not only to carry out the risk assessment, including its severity and probability, and also the likelihood that the unconformity will be detected before the product has reached the customer (Table 3);

- Establishing the results from the preliminary risk assessment for the process optimization through applying the necessary controls and carrying out a final RPN analysis (Table 3).

It is established that the analysis of critical factors should be carried out at least once per year, and at each change in the specification of the raw material. New raw materials or supplies should be added to the list only after making a documented analysis and assessment or each raw material or group of materials in accordance with Tables 2 and 3 with the aim of 
Table 2 Critical factors assessment for supplier approval.

\begin{tabular}{|c|c|c|c|c|c|c|c|c|c|c|c|c|c|c|}
\hline $\begin{array}{l}\text { Number } \\
\text { of } \\
\text { supplier }\end{array}$ & $\begin{array}{l}\text { Ingredients, } \\
\text { raw } \\
\text { materials }\end{array}$ & $\begin{array}{l}\text { Approved } \\
\text { questionnaire }\end{array}$ & $\begin{array}{l}\text { Easy } \\
\text { access } \\
\text { to the } \\
\text { raw } \\
\text { material }\end{array}$ & $\begin{array}{l}\text { GMO } \\
\text { status }\end{array}$ & *http://www.foodfraud.org/ & $\begin{array}{l}\text { Allergen } \\
\text { hazard }\end{array}$ & $\begin{array}{l}\text { Foreign } \\
\text { body } \\
\text { hazard }\end{array}$ & $\begin{array}{l}\text { Microbiological } \\
\text { hazard }\end{array}$ & $\begin{array}{l}\text { Toxicological } \\
\text { hazard }\end{array}$ & $\begin{array}{l}\text { Importance } \\
\text { for quality }\end{array}$ & $\begin{array}{l}\text { Complex } \\
\text { analysis } \\
\text { tests }\end{array}$ & $\begin{array}{l}\text { Complaints } \\
\text { from a } \\
\text { supplier }\end{array}$ & $\begin{array}{l}\text { Audit } \\
\text { decision }\end{array}$ & $\begin{array}{l}\text { Certification } \\
\text { status under } \\
\text { GFSI }\end{array}$ \\
\hline 1 & Sugar & Yes & $\mathrm{L}$ & $\mathrm{L}$ & M & $\mathrm{L}$ & $\mathrm{L}$ & $\mathrm{L}$ & $\mathrm{L}$ & $\mathrm{H}$ & $\mathrm{L}$ & $\mathrm{L}$ & No & Yes \\
\hline 2 & Sugar & Yes & $\mathrm{L}$ & $\mathrm{L}$ & M & $\mathrm{L}$ & $\mathrm{L}$ & $\mathrm{L}$ & $\mathrm{L}$ & $\mathrm{H}$ & $\mathrm{L}$ & $\mathrm{L}$ & No & Yes \\
\hline 3 & Sugar & Yes & $\mathrm{L}$ & $\mathrm{L}$ & M & $\mathrm{L}$ & M & $\mathrm{L}$ & $\mathrm{L}$ & $\mathrm{H}$ & $\mathrm{L}$ & $\mathrm{L}$ & No & No \\
\hline 4 & Sugar & Yes & $\mathrm{L}$ & $\mathrm{L}$ & M & $\mathrm{L}$ & M & $\mathrm{L}$ & $\mathrm{L}$ & $\mathrm{H}$ & $\mathrm{L}$ & $\mathrm{L}$ & No & No \\
\hline 5 & Sugar & Yes & $\mathrm{L}$ & $\mathrm{L}$ & M & $\mathrm{L}$ & M & $\mathrm{L}$ & $\mathrm{L}$ & $\mathrm{H}$ & $\mathrm{L}$ & $\mathrm{L}$ & No & No \\
\hline 6 & Flour & Yes & $\mathrm{L}$ & $\mathrm{L}$ & M & $\mathrm{H}$ & $\mathrm{H}$ & $\mathrm{L}$ & M & $\mathrm{L}$ & M & $\mathrm{L}$ & No & Yes \\
\hline 7 & Flour & Yes & $\mathrm{L}$ & $\mathrm{L}$ & M & $\mathrm{H}$ & $\mathrm{H}$ & L & M & M & M & L & Yes & No \\
\hline 8 & Flour & Yes & L & $\mathrm{L}$ & M & $\mathrm{H}$ & $\mathrm{H}$ & $\mathrm{L}$ & M & M & M & M & Yes & No \\
\hline 9 & Soy & Yes & $\mathrm{L}$ & $\mathrm{H}$ & M & $\mathrm{H}$ & $\mathrm{H}$ & L & L & M & M & $\mathrm{L}$ & Yes & No \\
\hline \multirow{4}{*}{10} & Milk powder & Yes & $\mathrm{L}$ & $\mathrm{L}$ & $\mathrm{H}$ & $\mathrm{H}$ & L & M & M & $\mathrm{L}$ & M & $\mathrm{L}$ & Yes & No \\
\hline & $\begin{array}{l}\text { Cocoa, } \\
\text { coconut }\end{array}$ & Yes & M & $\mathrm{L}$ & $\mathrm{H}$ & $\mathrm{L}$ & $\mathrm{L}$ & L & $\mathrm{L}$ & $\mathrm{H}$ & L & L & No & No \\
\hline & Palm oil & Yes & M & L & M & L & $\mathrm{L}$ & M & L & $\mathrm{L}$ & $\mathrm{L}$ & $\mathrm{L}$ & No & No \\
\hline & Whey & Yes & $\mathrm{H}$ & $\mathrm{L}$ & M & $\mathrm{H}$ & L & M & M & $\mathrm{L}$ & M & $\mathrm{L}$ & No & No \\
\hline \multirow{6}{*}{11} & Palm oil & Yes & $\mathrm{L}$ & $\mathrm{L}$ & M & $\mathrm{L}$ & $\mathrm{L}$ & L & $\mathrm{L}$ & $\mathrm{L}$ & L & $\mathrm{L}$ & No & Yes \\
\hline & Glucose & Yes & L & L & M & $\mathrm{L}$ & $\mathrm{L}$ & $\mathrm{L}$ & $\mathrm{L}$ & $\mathrm{L}$ & M & $\mathrm{L}$ & No & No \\
\hline & Additives & Yes & $\mathrm{L}$ & $\mathrm{L}$ & M & L & $\mathrm{L}$ & $\mathrm{L}$ & M & $\mathrm{L}$ & L & $\mathrm{L}$ & No & No \\
\hline & Starch & Yes & $\mathrm{L}$ & $\mathrm{L}$ & M & $\mathrm{H}$ & $\mathrm{L}$ & $\mathrm{L}$ & M & $\mathrm{L}$ & M & $\mathrm{L}$ & No & No \\
\hline & Lecithin & Yes & $\mathrm{L}$ & $\mathrm{H}$ & $\mathrm{H}$ & $\mathrm{H}$ & $\mathrm{L}$ & L & L & $\mathrm{H}$ & L & L & Yes & No \\
\hline & Margarine & Yes & $\mathrm{L}$ & $\mathrm{L}$ & M & L & $\mathrm{L}$ & $\mathrm{L}$ & $\mathrm{L}$ & $\mathrm{L}$ & L & $\mathrm{L}$ & No & No \\
\hline \multirow[t]{2}{*}{12} & $\begin{array}{l}\text { Couverture, } \\
\text { butter }\end{array}$ & Yes & $\mathrm{L}$ & $\mathrm{L}$ & M & L & $\mathrm{L}$ & $\mathrm{L}$ & $\mathrm{L}$ & M & M & $\mathrm{L}$ & No & No \\
\hline & Flavours & Yes & M & L & $\mathrm{H}$ & L & $\mathrm{L}$ & $\mathrm{L}$ & M & L & L & $\mathrm{L}$ & No & No \\
\hline 13 & $\begin{array}{l}\text { Cocoa, } \\
\text { cocoa mass }\end{array}$ & Yes & $\mathrm{L}$ & $\mathrm{L}$ & M & $\mathrm{L}$ & $\mathrm{L}$ & $\mathrm{L}$ & $\mathrm{L}$ & $\mathrm{H}$ & $\mathrm{L}$ & $\mathrm{L}$ & No & Yes \\
\hline 14 & Cocoa & Yes & $\mathrm{L}$ & $\mathrm{L}$ & M & $\mathrm{L}$ & $\mathrm{L}$ & $\mathrm{L}$ & M & $\mathrm{H}$ & L & $\mathrm{L}$ & No & No \\
\hline 15 & Flavours & Yes & M & L & $\mathrm{H}$ & $\mathrm{L}$ & $\mathrm{L}$ & $\mathrm{L}$ & M & $\mathrm{H}$ & M & L & No & No \\
\hline 16 & Flavours & Yes & M & $\mathrm{L}$ & $\mathrm{H}$ & $\mathrm{L}$ & $\mathrm{L}$ & L & M & $\mathrm{H}$ & M & $\mathrm{L}$ & No & No \\
\hline 17 & Flavours & Yes & M & L & $\mathrm{H}$ & $\mathrm{L}$ & $\mathrm{L}$ & $\mathrm{L}$ & M & $\mathrm{H}$ & M & $\mathrm{L}$ & No & No \\
\hline 18 & Flavours & Yes & M & $\mathrm{L}$ & $\mathrm{H}$ & L & $\mathrm{L}$ & L & M & $\mathrm{H}$ & M & L & No & No \\
\hline
\end{tabular}




\begin{tabular}{|c|c|c|c|c|c|c|c|c|c|c|c|c|c|c|}
\hline $\begin{array}{l}\text { Number } \\
\text { of } \\
\text { supplier }\end{array}$ & $\begin{array}{l}\text { Ingredients, } \\
\text { raw } \\
\text { materials }\end{array}$ & $\begin{array}{l}\text { Approved } \\
\text { questionnaire }\end{array}$ & $\begin{array}{l}\text { Easy } \\
\text { access } \\
\text { to the } \\
\text { raw } \\
\text { material }\end{array}$ & $\begin{array}{l}\text { GMO } \\
\text { status }\end{array}$ & *http://www.foodfraud.org/ & $\begin{array}{l}\text { Allergen } \\
\text { hazard }\end{array}$ & $\begin{array}{l}\text { Foreign } \\
\text { body } \\
\text { hazard }\end{array}$ & $\begin{array}{l}\text { Microbiological } \\
\text { hazard }\end{array}$ & $\begin{array}{l}\text { Toxicological } \\
\text { hazard }\end{array}$ & $\begin{array}{l}\text { Importance } \\
\text { for quality }\end{array}$ & $\begin{array}{l}\text { Complex } \\
\text { analysis } \\
\text { tests }\end{array}$ & $\begin{array}{l}\text { Complaints } \\
\text { from a } \\
\text { supplier }\end{array}$ & $\begin{array}{l}\text { Audit } \\
\text { decision }\end{array}$ & $\begin{array}{l}\text { Certification } \\
\text { status under } \\
\text { GFSI }\end{array}$ \\
\hline 19 & Flavours & Yes & M & $\mathrm{L}$ & $\mathrm{H}$ & $\mathrm{L}$ & $\mathrm{L}$ & $\mathrm{L}$ & M & $\mathrm{H}$ & M & $\mathrm{L}$ & No & Yes \\
\hline 20 & Flavours & Yes & M & $\mathrm{L}$ & $\mathrm{H}$ & $\mathrm{L}$ & $\mathrm{L}$ & $\mathrm{L}$ & M & $\mathrm{H}$ & M & $\mathrm{L}$ & No & No \\
\hline 21 & $\begin{array}{l}\text { Cocoa, } \\
\text { flavours }\end{array}$ & Yes & M & $\mathrm{L}$ & M & $\mathrm{L}$ & $\mathrm{L}$ & $\mathrm{L}$ & M & $\mathrm{H}$ & $\mathrm{L}$ & $\mathrm{L}$ & No & No \\
\hline 22 & Cows' butter & Yes & M & $\mathrm{L}$ & M & $\mathrm{H}$ & $\mathrm{L}$ & M & M & M & M & $\mathrm{L}$ & No & No \\
\hline 23 & Salt & Yes & $\mathrm{L}$ & $\mathrm{L}$ & M & $\mathrm{L}$ & $\mathrm{H}$ & $\mathrm{L}$ & $\mathrm{L}$ & M & $\mathrm{L}$ & $\mathrm{L}$ & No & No \\
\hline 24 & Egg mixure & Yes & M & $\mathrm{L}$ & M & $\mathrm{H}$ & $\mathrm{L}$ & $\mathrm{H}$ & M & $\mathrm{H}$ & M & $\mathrm{L}$ & Yes & No \\
\hline \multirow{2}{*}{25} & Malt extract & Yes & $\mathrm{H}$ & L & M & $\mathrm{H}$ & $\mathrm{L}$ & $\mathrm{L}$ & M & M & L & $\mathrm{L}$ & No & Yes \\
\hline & Gelatin & Yes & $\mathrm{H}$ & $\mathrm{H}$ & $\mathrm{H}$ & $\mathrm{L}$ & $\mathrm{L}$ & $\mathrm{L}$ & M & $\mathrm{H}$ & L & $\mathrm{L}$ & Yes & No \\
\hline 26 & Cocoa & Yes & $\mathrm{L}$ & $\mathrm{L}$ & M & $\mathrm{L}$ & $\mathrm{L}$ & $\mathrm{L}$ & M & M & L & $\mathrm{L}$ & No & No \\
\hline 27 & Fruit fillings & Yes & L & $\mathrm{L}$ & M & L & $\mathrm{L}$ & $\mathrm{L}$ & L & $\mathrm{H}$ & L & $\mathrm{L}$ & No & Yes \\
\hline 28 & Sesame & Yes & L & $\mathrm{L}$ & M & $\mathrm{H}$ & $\mathrm{L}$ & $\mathrm{L}$ & $\mathrm{L}$ & $\mathrm{L}$ & $\mathrm{L}$ & $\mathrm{L}$ & No & No \\
\hline 29 & Sesame & Yes & L & $\mathrm{L}$ & M & $\mathrm{H}$ & $\mathrm{L}$ & $\mathrm{L}$ & $\mathrm{L}$ & $\mathrm{L}$ & $\mathrm{L}$ & $\mathrm{L}$ & No & No \\
\hline 30 & $\begin{array}{l}\text { Ammonium } \\
\text { bicarbonate }\end{array}$ & Yes & L & $\mathrm{L}$ & M & L & $\mathrm{L}$ & $\mathrm{L}$ & $\mathrm{L}$ & $\mathrm{L}$ & L & $\mathrm{L}$ & No & Yes \\
\hline 31 & Additives & Yes & M & L & M & L & $\mathrm{L}$ & $\mathrm{L}$ & $\mathrm{L}$ & $\mathrm{H}$ & M & L & No & No \\
\hline 32 & Nuts & Yes & $\mathrm{L}$ & $\mathrm{L}$ & M & $\mathrm{H}$ & $\mathrm{H}$ & $\mathrm{L}$ & M & M & M & L & No & No \\
\hline 33 & Nuts & Yes & $\mathrm{L}$ & $\mathrm{L}$ & M & $\mathrm{H}$ & $\mathrm{H}$ & $\mathrm{L}$ & M & M & M & M & No & No \\
\hline 34 & Nuts & Yes & $\mathrm{L}$ & $\mathrm{L}$ & M & $\mathrm{H}$ & $\mathrm{H}$ & L & M & M & M & $\mathrm{L}$ & No & No \\
\hline 35 & Oat flakes & Yes & L & $\mathrm{L}$ & M & $\mathrm{H}$ & $\mathrm{L}$ & L & M & M & M & L & No & Yes \\
\hline 36 & Milk powder & Yes & $\mathrm{L}$ & $\mathrm{L}$ & $\mathrm{H}$ & $\mathrm{H}$ & $\mathrm{L}$ & M & M & $\mathrm{H}$ & L & $\mathrm{L}$ & No & Yes \\
\hline 37 & Whey & Yes & H & $\mathrm{L}$ & M & $\mathrm{H}$ & L & M & M & $\mathrm{L}$ & M & $\mathrm{L}$ & No & Yes \\
\hline 38 & Margarine & Yes & $\mathrm{L}$ & $\mathrm{L}$ & M & $\mathrm{L}$ & $\mathrm{L}$ & $\mathrm{L}$ & $\mathrm{L}$ & $\mathrm{L}$ & L & $\mathrm{L}$ & No & Yes \\
\hline 39 & Palm oil & Yes & $\mathrm{L}$ & L & M & $\mathrm{L}$ & $\mathrm{L}$ & $\mathrm{L}$ & $\mathrm{L}$ & L & L & $\mathrm{L}$ & No & Yes \\
\hline 40 & Cocoa & Yes & L & $\mathrm{L}$ & M & $\mathrm{L}$ & $\mathrm{L}$ & $\mathrm{L}$ & M & $\mathrm{L}$ & L & $\mathrm{L}$ & No & No \\
\hline 41 & Palm oil & Yes & L & $\mathrm{L}$ & M & $\mathrm{L}$ & $\mathrm{L}$ & $\mathrm{L}$ & $\mathrm{L}$ & $\mathrm{H}$ & L & $\mathrm{L}$ & No & No \\
\hline 42 & Tahini & Yes & $\mathrm{L}$ & $\mathrm{L}$ & M & M & $\mathrm{L}$ & $\mathrm{L}$ & $\mathrm{L}$ & $\mathrm{L}$ & $\mathrm{L}$ & $\mathrm{L}$ & No & Yes \\
\hline 43 & Tahini & Yes & L & $\mathrm{L}$ & M & M & $\mathrm{L}$ & $\mathrm{L}$ & L & $\mathrm{L}$ & $\mathrm{L}$ & $\mathrm{L}$ & No & Yes \\
\hline 44 & Whey & Yes & $\mathrm{L}$ & $\mathrm{L}$ & M & $\mathrm{H}$ & $\mathrm{L}$ & $\mathrm{L}$ & $\mathrm{L}$ & $\mathrm{L}$ & $\mathrm{L}$ & $\mathrm{L}$ & No & No \\
\hline 45 & Salt & Yes & $\mathrm{L}$ & L & M & L & $\mathrm{H}$ & L & $\mathrm{L}$ & $\mathrm{L}$ & $\mathrm{L}$ & $\mathrm{L}$ & No & Yes \\
\hline
\end{tabular}

Legend: Ingredient Risk: $\mathrm{E}=$ Extra Controls $\mathrm{H}=$ High, $\mathrm{M}=$ Medium $\mathrm{L}=$ Low. 
Table 3 Risk rating of raw materials and supplies and determination.

\begin{tabular}{|c|c|c|c|c|}
\hline nent & RPN & $\mathrm{P}$ & $\mathrm{R}$ & $\mathrm{N}$ \\
\hline $\begin{array}{l}\text { RPN above } \\
730\end{array}$ & $\begin{array}{l}\text { Very high RPN risk rating. There is a high risk } \\
\text { that the raw material is counterfeited, falsified } \\
\text { or does not meet the specifications agreed in } \\
\text { advance. }\end{array}$ & $\begin{array}{l}7-10=\text { Considerable } \\
\text { severity and customer } \\
\text { exodus, financial losses }\end{array}$ & $\begin{array}{l}7-10=\text { Very high } \\
\text { probability that the } \\
\text { event occurs once per } \\
\text { year }\end{array}$ & $\begin{array}{l}7-10=\text { Likelihood } \\
\text { for detection less } \\
\text { than } 10 \%\end{array}$ \\
\hline $\begin{array}{l}\text { RPN up to } \\
350\end{array}$ & $\begin{array}{l}\text { Moderate RPN risk rating. } \\
\text { There is a moderate risk that the raw material } \\
\text { is counterfeited, falsified or does not meet the } \\
\text { specifications agreed in advance. }\end{array}$ & $\begin{array}{l}4-6=\text { Moderate severity } \\
\text { with average negative } \\
\text { impact on consumers } \\
\text { usually related to limited } \\
\text { market or target group. }\end{array}$ & $\begin{array}{l}4-6=\text { Probability that } \\
\text { the event occurs less } \\
\text { than once per year }\end{array}$ & $\begin{array}{l}4-6=\text { Little } \\
\text { likelihood for } \\
\text { detection up to } 35 \%\end{array}$ \\
\hline $\begin{array}{l}\text { RPN up to } \\
65\end{array}$ & $\begin{array}{l}\text { Low RPN risk rat } \\
\text { that the raw mate } \\
\text { contamination, co }\end{array}$ & $\begin{array}{l}2-3=\text { Low severity with } \\
\text { insignificant impact on } \\
\text { particular consumers }\end{array}$ & $\begin{array}{l}2-3=\text { Probability that } \\
\text { the event occurs once } \\
\text { per } 5 \text { years }\end{array}$ & $\begin{array}{l}2-3=\text { Medium } \\
\text { likelihood for } \\
\text { detection up to } 80 \%\end{array}$ \\
\hline $\begin{array}{l}\text { RPN up to } \\
10\end{array}$ & $\begin{array}{l}\text { Minor RPN risk rating. There is an } \\
\text { insignificant or negligible risk that the raw } \\
\text { material is subject to intentional } \\
\text { contamination, counterfeit or falsification. }\end{array}$ & $1=$ No identified severity & $\begin{array}{l}1=\text { Small probability } \\
\text { that the event occurs }\end{array}$ & $\begin{array}{l}1=\text { High likelihood } \\
\text { for detection up to } \\
100 \%\end{array}$ \\
\hline
\end{tabular}

identifying the potential risks for the safety of products, the compliance with the law and the quality. The analysis took into account all factors critical for the safety such as: microbiological, toxicological and physical contamination; cross contamination with allergens; possible counterfeit and fraud (verification is carried out in the portal http://www.foodfraud.org/) and others. Besides on the quoted webpage, the data related to counterfeit and or food fraud were verified through other sources of information. It is established that the quality related critical factors are the experience of the supplier in quality management and his certification status under GFSI; recommendations for good performance and last but not least_ - price of the raw materials offered by them. It is established that the management related to the assessment of critical factors in the supplier approval process is a prerequisite for meeting customer requirements and achieving customer satisfaction.

The result from the critical factors analysis of the risk and supplier approval shows that of all raw materials used, egg mixture, lecithin, soy, milk powder and whey have highest risk ratings. Assessment risk was carried out for 45 suppliers of raw materials for manufacturing biscuit product, which is given in Table 2. The analysis aims to guarantee that the planned, stored and used raw materials and supplies meet the requirements of the legislation and do not jeopardize the safety and the quality of manufactured products and the services rendered to the customer. Regardless of the assessment, the suppliers should confirm that the content of pesticides, chemical residues, microbiological and physical contaminators in the raw materials supplied by them do not exceed the values of the imposed restriction, published in the internationally recognized regulations and codes.

The next stage in the approval of raw material suppliers for biscuit manufacturing is determining and calculating the preliminary risk level according to RPN.

Determining the numerical value of the severity, probability and the risk detection for each supplier and respectively the supplied raw material gives values from 01 up to 10 , the rating of which is shown in Table 3 .

In biscuit manufacturing the risks related to food quality and safety can be very often contradictory. From the point of view of the microbiological safety of products baking should be carried out at the highest possible temperature and for a long time, but this would deteriorate most of the sensory indicators of these products and make them probably undesirable for consumption regardless of their safety. The purpose of determining the risk severity is exactly to detect raw materials which are critical for the product 
safety and at the next stage to find ways for this risk to be reduced to an acceptable level. Allergens are the most serious risk for food safety but only for the vulnerable groups of the population. The content of peanuts, which is not indicated on the label, can be fatal for the vulnerable consumers, which is why allergens are given the highest level of severity in risk assessment.

The difference between the preliminary and the final RPN analysis is due to the reduction of the risk after accepting control measures, which can be: temperature control of storage and baking, introduction of metal detectors, confirmation for compliant labeling, inspection of hygienic conditions, etc. The assessment for RPN allows informed decision-taking depending on the effect of the changes in the business environment. Although biscuit manufacturing has been always considered low-risk, the latest studies have established that the RPN level can increase to a very high risk rating when using raw cocoa, unbaked peanut products, milk powder with melanin, as well as cross contamination with allergens at the supplier. The results from the actual RPN assessment are given in Table 4.

The purpose of making analysis of raw materials and suppliers through the FMEA method is to detect potential weaknesses in the supply chain, in order to prevent non-conformities, which may arise as result of the risk. All issues included in the risk analysis applied in Table 3 direct the attention to potential problems and identify the raw materials which have higher RPN, in order to undertake the necessary controls and to manage the risk. Following the application of the analysis it became clear that the raw materials with higher RPN up to 350 , which corresponds to moderate risk rating, are: cows' butter,

Table 4 Preliminary and final RPN.

\begin{tabular}{|l|l|l|l|l|l|}
\hline \multirow{2}{*}{ PLAN } & $\begin{array}{l}\text { FMEA form for analysis of } \\
\text { different non-conformities } \\
\text { (failures) and their effects. } \\
\text { (PLAN-DO-CHECK-ACT) }\end{array}$ & \begin{tabular}{l} 
Process owner: \\
\cline { 3 - 4 }
\end{tabular} & $\begin{array}{l}\text { Moderator / Risk } \\
\text { manager: }\end{array}$ & $\begin{array}{l}\text { Date of control } \\
\text { confirmation: }\end{array}$ & Date of first issue: \\
Team leader: & Need of follow up actions \\
\hline DO & Date of change: & ACT \\
\hline
\end{tabular}

\begin{tabular}{|c|c|c|c|c|c|c|c|c|c|c|c|c|c|}
\hline \multirow{2}{*}{ No. } & \multirow{2}{*}{ Raw material } & \multicolumn{4}{|c|}{ Preliminary } & \multirow{2}{*}{$\begin{array}{l}\text { Audit } \\
\text { decision }\end{array}$} & \multirow{2}{*}{$\begin{array}{l}\text { Supplier } \\
\text { approval }\end{array}$} & \multirow{2}{*}{ Control measure * } & \multicolumn{4}{|c|}{ Final RPN } & \multirow{2}{*}{$\begin{array}{l}\text { Sufficiency } \\
\text { mode }\end{array}$} \\
\hline & & $\overline{\mathrm{O}}$ & $\mathrm{S}$ & $\mathrm{D}$ & RPN & & & & $\mathrm{O}$ & $\mathrm{S}$ & $\mathrm{D}$ & RPN & \\
\hline 1 & Sugar & 4 & 4 & 3 & 48 & Yes & Yes & $1 ; 5 ; 6 ; 7 ; 8 ; 10$ & 4 & 3 & 2 & 24 & Yes \\
\hline 2 & Sugar & 4 & 4 & 3 & 48 & Yes & Yes & $1 ; 5 ; 6 ; 7 ; 8 ; 10$ & 4 & 3 & 2 & 24 & Yes \\
\hline 3 & Sugar & 4 & 4 & 3 & 48 & Yes & Yes & $1 ; 5 ; 6 ; 7 ; 8 ; 10$ & 4 & 3 & 2 & 24 & Yes \\
\hline 4 & Sugar & 4 & 4 & 3 & 48 & Yes & Yes & $1 ; 5 ; 6 ; 7 ; 8 ; 10$ & 4 & 3 & 2 & 24 & Yes \\
\hline 5 & Sugar & 4 & 4 & 3 & 48 & Yes & Yes & $1 ; 5 ; 6 ; 7 ; 8 ; 10$ & 4 & 3 & 2 & 24 & Yes \\
\hline 6 & Flour & 2 & 5 & 4 & 40 & Yes & Yes & $1 ; 3 ; 5 ; 6 ; 7 ; 8 ; 10$ & 2 & 4 & 2 & 16 & Yes \\
\hline 7 & Flour & 2 & 5 & 4 & 40 & Yes & Yes & $1 ; 5 ; 3 ; 6 ; 7 ; 8 ; 10$ & 2 & 4 & 3 & 24 & Yes \\
\hline 8 & Flour & 2 & 5 & 4 & 40 & Yes & Yes & $1 ; 5 ; 3 ; 6 ; 7 ; 8 ; 10$ & 2 & 4 & 3 & 24 & Yes \\
\hline \multirow[t]{2}{*}{9} & Soy & 2 & 4 & 7 & 56 & Yes & Yes & $1 ; 5 ; 6 ; 7 ; 8 ; 9 ; 10$ & 2 & 3 & 3 & 18 & Yes \\
\hline & Milk powder & 6 & 7 & 6 & 252 & Yes & Yes & $1 ; 5 ; 6 ; 7 ; 8 ; 9 ; 10$ & 6 & 5 & 4 & 120 & Yes \\
\hline \multirow{5}{*}{10} & Cocoa, coconut & 3 & 3 & 4 & 36 & Yes & Yes & $1 ; 5 ; 6 ; 7 ; 8 ; 10$ & 3 & 2 & 2 & 12 & Yes \\
\hline & Palm oil & 3 & 3 & 2 & 18 & Yes & Yes & $1 ; 5 ; 6 ; 7 ; 8 ; 10$ & 3 & 2 & 2 & 12 & Yes \\
\hline & Whey & 6 & 7 & 6 & 252 & Yes & Yes & $1 ; 5 ; 6 ; 7 ; 8 ; 9 ; 10$ & 6 & 5 & 4 & 120 & Yes \\
\hline & Palm oil & 3 & 3 & 4 & 36 & Yes & Yes & $1 ; 5 ; 6 ; 7 ; 8 ; 10$ & 3 & 2 & 2 & 12 & Yes \\
\hline & Glucose & 3 & 3 & 2 & 18 & Yes & Yes & $1 ; 5 ; 6 ; 7 ; 8 ; 10$ & 3 & 2 & 2 & 12 & Yes \\
\hline \multirow{4}{*}{11} & Additives & 3 & 3 & 2 & 18 & Yes & Yes & $1 ; 5 ; 6 ; 7 ; 8 ; 10$ & 3 & 2 & 2 & 12 & Yes \\
\hline & Starch & 2 & 7 & 4 & 56 & Yes & Yes & $1 ; 5 ; 6 ; 7 ; 8 ; 10$ & 2 & 5 & 2 & 20 & Yes \\
\hline & Lecithin & 3 & 4 & 7 & 84 & Yes & Yes & $1 ; 2 ; 3 ; 5 ; 6 ; 7 ; 8 ; 10$ & 3 & 2 & 5 & 30 & Yes \\
\hline & Margarine & 3 & 4 & 3 & 36 & Yes & Yes & $1 ; 5 ; 6 ; 7 ; 8 ; 10$ & 3 & 2 & 2 & 12 & Yes \\
\hline
\end{tabular}


(Table 4 continued)

\begin{tabular}{|c|c|c|c|c|c|c|c|c|c|c|c|c|c|}
\hline \multirow{2}{*}{ No. } & \multirow{2}{*}{ Raw material } & \multicolumn{4}{|c|}{ Preliminary } & \multirow{2}{*}{$\begin{array}{l}\text { Audit } \\
\text { decision }\end{array}$} & \multirow{2}{*}{$\begin{array}{l}\text { Supplier } \\
\text { approval }\end{array}$} & \multirow{2}{*}{ Control measure * } & \multicolumn{4}{|c|}{ Final RPN } & \multirow{2}{*}{$\begin{array}{l}\text { Sufficiency } \\
\text { mode }\end{array}$} \\
\hline & & $\mathrm{O}$ & $\mathrm{S}$ & $\mathrm{D}$ & RPN & & & & $\mathrm{O}$ & $\mathrm{S}$ & $\mathrm{D}$ & RPN & \\
\hline \multirow{2}{*}{12} & Couverture, butter & 3 & 3 & 4 & 36 & Yes & Yes & $1 ; 5 ; 6 ; 7 ; 8 ; 10$ & 3 & 2 & 2 & 12 & Yes \\
\hline & Flavours & 2 & 4 & 7 & 56 & Yes & Yes & $1 ; 5 ; 6 ; 7 ; 8 ; 10$ & 2 & 3 & 5 & 30 & Yes \\
\hline 13 & Cocoa, cocoa mass & 3 & 3 & 2 & 18 & Yes & Yes & $1 ; 5 ; 6 ; 7 ; 8 ; 10$ & 3 & 2 & 2 & 12 & Yes \\
\hline 14 & Cocoa & 3 & 3 & 4 & 36 & Yes & Yes & $1 ; 5 ; 6 ; 7 ; 8 ; 10$ & 3 & 2 & 2 & 12 & Yes \\
\hline 15 & Flavours & 2 & 4 & 7 & 56 & Yes & Yes & $1 ; 5 ; 6 ; 7 ; 8 ; 10$ & 2 & 3 & 5 & 30 & Yes \\
\hline 16 & Flavours & 2 & 4 & 7 & 56 & Yes & Yes & $1 ; 5 ; 6 ; 7 ; 8 ; 10$ & 2 & 3 & 5 & 30 & Yes \\
\hline 17 & Flavours & 2 & 4 & 7 & 56 & Yes & Yes & $1 ; 5 ; 6 ; 7 ; 8 ; 10$ & 2 & 3 & 5 & 30 & Yes \\
\hline 18 & Flavours & 2 & 4 & 7 & 56 & Yes & Yes & $1 ; 5 ; 6 ; 7 ; 8 ; 10$ & 2 & 3 & 5 & 30 & Yes \\
\hline 19 & Flavours & 2 & 4 & 7 & 56 & Yes & Yes & $1 ; 5 ; 6 ; 7 ; 8 ; 10$ & 2 & 3 & 5 & 30 & Yes \\
\hline 20 & Flavours & 2 & 4 & 7 & 56 & Yes & Yes & $1 ; 5 ; 6 ; 7 ; 8 ; 10$ & 2 & 3 & 5 & 30 & Yes \\
\hline 21 & Cocoa, flavours & 3 & 3 & 4 & 36 & Yes & Yes & $1 ; 5 ; 6 ; 7 ; 8 ; 10$ & 3 & 2 & 2 & 12 & Yes \\
\hline 22 & Cows' butter & 7 & 6 & 7 & 294 & Yes & Yes & $1 ; 2 ; 5 ; 6 ; 7 ; 8 ; 9 ; 10$ & 7 & 4 & 5 & 140 & Yes \\
\hline 23 & Salt & 3 & 4 & 3 & 36 & Yes & Yes & $1 ; 5 ; 6 ; 7 ; 8 ; 10$ & 3 & 2 & 2 & 12 & Yes \\
\hline 24 & Egg mixture & 7 & 6 & 7 & 294 & Yes & Yes & $1 ; 2 ; 5 ; 6 ; 7 ; 8 ; 9 ; 10$ & 7 & 4 & 5 & 140 & Yes \\
\hline \multirow{2}{*}{25} & Malt extract & 2 & 7 & 4 & 56 & Yes & Yes & $1 ; 5 ; 6 ; 7 ; 8 ; 10$ & 2 & 5 & 2 & 20 & Yes \\
\hline & Gelatin & 4 & 5 & 7 & 140 & Yes & Yes & $1 ; 2 ; 3 ; 5 ; 6 ; 7 ; 8 ; 10$ & 4 & 3 & 5 & 60 & Yes \\
\hline 26 & Cocoa & 3 & 3 & 4 & 36 & Yes & Yes & $1 ; 5 ; 6 ; 7 ; 8 ; 10$ & 3 & 3 & 2 & 18 & Yes \\
\hline 27 & Fruit fillings & 2 & 5 & 4 & 40 & Yes & Yes & $1 ; 5 ; 6 ; 7 ; 8 ; 10$ & 2 & 2 & 2 & 8 & Yes \\
\hline 28 & Sesame & 3 & 3 & 4 & 36 & Yes & Yes & $1 ; 5 ; 6 ; 7 ; 8 ; 10$ & 3 & 2 & 2 & 12 & Yes \\
\hline 29 & Sesame & 3 & 3 & 4 & 36 & Yes & Yes & $1 ; 5 ; 6 ; 7 ; 8 ; 10$ & 3 & 2 & 2 & 12 & Yes \\
\hline 30 & $\begin{array}{l}\text { Ammonium } \\
\text { bicarbonate }\end{array}$ & 2 & 3 & 5 & 30 & Yes & Yes & $1 ; 5 ; 6 ; 7 ; 8 ; 10$ & 2 & 2 & 2 & 8 & Yes \\
\hline 31 & Additives & 2 & 4 & 3 & 24 & Yes & Yes & $1 ; 5 ; 6 ; 7 ; 8 ; 10$ & 2 & 2 & 2 & 8 & Yes \\
\hline 32 & Nuts & 2 & 7 & 7 & 98 & Yes & Yes & $1 ; 5 ; 6 ; 7 ; 8 ; 10$ & 2 & 5 & 5 & 50 & Yes \\
\hline 33 & Nuts & 2 & 7 & 7 & 98 & Yes & Yes & $1 ; 5 ; 6 ; 7 ; 8 ; 10$ & 2 & 5 & 5 & 50 & Yes \\
\hline 34 & Nuts & 2 & 7 & 7 & 98 & Yes & Yes & $1 ; 5 ; 6 ; 7 ; 8 ; 10$ & 2 & 5 & 5 & 50 & Yes \\
\hline 35 & Oat flakes & 2 & 5 & 4 & 40 & Yes & Yes & $1 ; 5 ; 6 ; 7 ; 8 ; 10$ & 2 & 3 & 2 & 12 & Yes \\
\hline 36 & Milk powder & 6 & 7 & 6 & 252 & Yes & Yes & $1 ; 5 ; 6 ; 7 ; 8 ; 10$ & 6 & 5 & 4 & 120 & Yes \\
\hline 37 & Whey & 6 & 7 & 6 & 252 & Yes & Yes & $1 ; 5 ; 6 ; 7 ; 8 ; 10$ & 6 & 5 & 4 & 120 & Yes \\
\hline 38 & Margarine & 2 & 4 & 7 & 56 & Yes & Yes & $1 ; 5 ; 6 ; 7 ; 8 ; 10$ & 2 & 2 & 5 & 20 & Yes \\
\hline 39 & Palm oil & 2 & 4 & 7 & 56 & Yes & Yes & $1 ; 5 ; 6 ; 7 ; 8 ; 10$ & 2 & 2 & 5 & 20 & Yes \\
\hline 40 & Cocoa & 3 & 3 & 4 & 36 & Yes & Yes & $1 ; 5 ; 6 ; 7 ; 8 ; 10$ & 3 & 2 & 2 & 12 & Yes \\
\hline 41 & Palm oil & 3 & 3 & 2 & 18 & Yes & Yes & $1 ; 5 ; 6 ; 7 ; 8 ; 10$ & 3 & 2 & 2 & 12 & Yes \\
\hline 42 & Tahini & 3 & 3 & 2 & 18 & Yes & Yes & $1 ; 5 ; 6 ; 7 ; 8 ; 10$ & 3 & 2 & 2 & 12 & Yes \\
\hline 43 & Tahini & 2 & 7 & 4 & 56 & Yes & Yes & $1 ; 5 ; 6 ; 7 ; 8 ; 10$ & 2 & 5 & 2 & 20 & Yes \\
\hline 44 & Whey & 6 & 7 & 7 & 294 & Yes & Yes & $1 ; 5 ; 6 ; 7 ; 8 ; 10$ & 6 & 5 & 5 & 150 & Yes \\
\hline 45 & Salt & 3 & 3 & 2 & 18 & Yes & Yes & $1 ; 5 ; 6 ; 7 ; 8 ; 10$ & 3 & 2 & 2 & 12 & Yes \\
\hline
\end{tabular}

Legend: *

*Preventive or control measures specified in the column "Control measures" include:

1. Certificates of analysis from suppliers of raw materials.

2. Analyses of raw materials or finished products carried out in the enterprise and by the enterprise.

3. Audits of the supply chain or certificate under GFSI.

4. Changes in the supply chain or replacement of the raw material source.

5. Application of evidence for unpacking or label on the raw material.

6. Detailed analysis before supplier approval.

7. "Mass balance".

8. Procedure for process monitoring (monitoring of $\mathrm{CCP}$, temperature, time, $\mathrm{pH}, \mathrm{Aw}$ and sensory parameters such as appearance and texture). 9. Possible corrections if the system is out of control and confirmation of product specification by a technologist.

10. Positive confirmation by a technologist before using the raw material, the semi-finished material, the supply. 
milk powder, whey, nuts, gelatin and soy products (including lecithin). Suitable risk minimizing controls can enable the raw materials management system (as part of the entire quality and safety management system) to prevent the supply and use of raw materials which are not in conformity with the specification.

\section{Discussion}

An important condition to make risk assessment a useful instrument for the management of raw materials is that it should be continuously updated. This requires making a review of the assessment at least on annual basis and also in case of a substantial change in the origin, price, supply chain of the raw material or its supplier. Where the risk analysis of the raw material has established high levels of RPN, it may become necessary to carry out a compliance audit or certificate of conformity by a third party with recognized GFSI scheme, in order to guarantee the efficient management of identified risks.

A more efficient management can be achieved by means of combining risk analysis and optimum incoming control which, apart from requiring certificates for authenticity and conformity, should include also making laboratory analysis of raw materials. The application of a comprehensive policy for the management of raw materials can guarantee that all incoming raw materials and supplies meet the applicable standards before entering the storage spaces of the manufacturer.

\section{Conclusions}

The application of the FMEA method for risk assessment allows also making assessment of the possibilities for establishing non-conformities with the specification of raw materials before the product has reached the consumer. This method is currently recognized because the assessment methods existing so far have not been sufficiently effective. In most cases, the severity of a risk event which has occurred as result of using a raw material non-conforming with the specification is high, because it is impossible to manufacture a final product meeting the specification with non-conforming raw materials. Furthermore, the use of raw materials in non-conformity with the quality and safety criteria and standards is most often the cause that the final product does not comply with the legislation, which always leads to severe implications for the producer. Apart from this, the proposed method allows to make assessment not only of the severity from the point of view of safety, but also of the impact of raw materials related to quality management.

The consequences from neglecting the process of risk identification and management can be great financial losses and customer exodus as result from complaints. Besides the adequate risk management, it is also necessary to apply suitable controls for minimizing the risk related to the safety and quality of biscuit products. The analysis carried out according to the FMEA method has proved that the implementation of an integrated management approach in solving the problems related to authenticity, quality and safety of raw materials, helps achieving a quality of biscuit products which meets customer requirements.

\section{Acknowledgments}

We would like to express our thanks to ZIV Ltd., Bulgaria who gave us the opportunity to implement the model of integrated management system in two plants for manufacturing confectionery products.

\section{References}

[1] Baltsavias, A. J., and Van Vliet, T. 1999. "Properties of Short-Dough Biscuits in Relation to Structure." Journal of Cereal Science 29 (3): 245-55.

[2] Jacob, J., and Leelavathi, K. 2007. "Effect of Fat-Type on Cookie Dough and Cookie Quality." Journal of Food Engineering 79 (1): 299-305.

[3] Laguna, L., Salvador, A., Sanz, T., and Fiszman, M. 2011. "Performance of a Resistant Starch Rich Ingredient in the Baking and Eating Quality of Short-Dough Biscuits." LWT-Food Science and Technology 44 (3): 737-46.

[4] Abboud, M., Rubenthaler, G., and Hoseney, R. 1985. 
"Effect of Fat and Sugar in Sugar-Snap Cookies and Evaluation of Tests to Measure Cookie Flour Quality." Cereal Chem 62 (2): 124-9.

[5] Chevallier, S., Colonna, P., Della Valle, G., and Lourdin, D. 2000. "Contribution of Major Ingredients during Baking of Biscuit Dough Systems." Journal of Cereal Science 31 (3): 241-52.

[6] Pedersen, L., Kaack, K., Bergsoe, N., and Adler-Nissen, J. 2004. "Rheological Properties of Biscuit Dough from Different Cultivars, and Relationship to Baking Characteristics." Journal of Cereal Science 39 (1): 37-46.

[7] Maache-Rezzoug, Z., Bouvier, M., Allaf, K., and Patras, C. 1998. "Effect of Principal Ingredients on Rheological Behaviour of Biscuit Dough and on Quality of Biscuits." Journal of Food Engineering 35 (1): 23-42.

[8] Manohar, S., and Haridas Rao, P. 1997. "Effect of Sugars on the Rheological Characteristics of Biscuit Dough and Quality of Biscuits." Journal of the Science of Food and Agriculture 75 (3): 383-90.

[9] Pasha, I., Butt, S., Anjum, F., and Shehzadi, N. 2002. "Effect of Dietetic Sweeteners on the Quality of Cookies." Analysis 8 (60): 20.

[10] Gallagher, E., O'brien, M., Scannell, M., and Arendt, K. 2003. "Evaluation of Sugar Replacers in Short Dough Biscuit Production." Journal of Food Engineering 56 (2): 261-3.

[11] Ames, J. 1998. "Applications of the Maillard Reaction in the Food Industry." Food Chemistry 62 (4): 431-9.

[12] Manohar, S., and Haridas, P. 1999. "Effects of Water on the Rheological Characteristics of Biscuit Dough and Quality of Biscuits." European Food Research and Technology 209 (3-4): 281-5.

[13] Gallagher, E., Sheila, K., and Arendt, E. 2005. "Impact of Dairy Protein Powders on Biscuit Quality." European Food Research and Technology 221 (3-4): 237-43.

[14] Phillips, G., and Williams, P. 2011. Handbook of Food Proteins, 1st ed. Elsevier.

[15] Barnett, L., Muncer, K., Grimshaw, K., Shepherd, R., and Raats, M. 2011. "How do Peanut and Nut-Allergic Consumers Use Information on the Packaging to Avoid Allergens?" Allergy 66 (7): 969-78.

[16] Cadbury, D. 2011. Chocolate Wars: The 150-year Rivalry between the World's Greatest Chocolate Makers. 1st ed. London: Harper Press.

[17] Afoakwa, E. 2016. Chocolate Science and Technology. 2nd ed. London: Wiley-Blackwell.

[18] Indrani, D., and Rao, G. 2008. "Functions of Ingredients in the Baking of Sweet Goods." Food Engineering Aspects of Baking Sweet Goods 31-47.

[19] Whitehurst, R. 2008. Emulsifiers in Food Technology, 1st ed. Northhampton, UK: John Wiley \& Sons, 7-57.

[20] Cauvain, S., and Young, L. 2006. Baked Products: Science, Technology and Practice, 1st ed. Oxford: Blackwell Publishing Ltd, 43-89. 